トピックス

$$
\text { メニエール病と遺伝子 }
$$

野口 佳裕

\title{
Meniere's disease and gene
}

\author{
Yoshihiro Noguchi
}

Department of Otolaryngology, Tokyo Medical and Dental University

\section{はじめに}

メニエール病の病因として, 遺伝要因, 解剖学 的要因, 外傷, ウイルス感染, アレルギー, 自己 免疫異常, 血管障害, 心身症的要因などが考えら れている11。遺伝要因に関しては, メニエール病 は 4-20\%に家族内発症が認められ, $60 \%$ 程度の 浸透率を有する常染色体優性遺伝性疾患とする報 告がある ${ }^{23)}$ 。これまでのメニエール病に関する遺 伝学的研究は, 孤発例を中心とした関連解析と家 族性メニエール病に対する連鎖解析に大別でき る。近年, 関連解析としては Lopez-Escamezら のグループが精力的な研究を行っている。また,

連鎖解析としては, 常染色体優性遺伝のメニエー ル病家系において原因候補遺伝子が同定されつつ ある ${ }^{4)}$ 。本稿では, これまでのメニエール病に関 する遺伝子研究について述べたい。

\section{メニエール病に対する関連解析}

1. HLA

HLA は第 6 番染色体短腕に存在する主要組織 適合遺伝子複合体 (MHC： major histocompatibility complex）にある MHC（HLA）遺伝子群によ りコードされる抗原であり, クラス I 分子 (HLAA, HLA-B, HLA-C) とクラス II 分子 (HLADR, HLA-DQ, HLA-DP) に分類される。免疫 系に重要な働きをしており, 各種自己免疫疾患と HLA との関連が報告されている。

東京医科歯科大学耳鼻咽喉科
メニエール病においても HLAに関する複数の 報告がなされている ${ }^{5) \sim 10)}$ (表 1)。近年, Koo ら ( $^{8)}$ はメニエール病例をコラーゲン II 抗体に対する 自己抗体の有無で分類し, 抗コラーゲン II 抗体 陽性例では HLA-DRB 1*0405の頻度が有意に高 いこと, 抗コラーゲン II 抗体陰性例では HLADRB 1*1201が有意に高く, HLA-DRB 1*13が有 意に低いことを報告した。一方， Lopez-Escamez

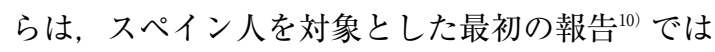
HLA-A，-B，-C，-DR とメニエール病との関連 はないとしながらも, 後に病状が重篤と考えられ る両側のメニエール病例のみを対象として HLADRB $1^{*} 1101$ が有意に関連することを報告した9)。 これら多数の HLAアリルが同定されてきた理由 として,メニエール病の診断基準の相違や人種差 による影響が一因として挙げられる。しかし，韓

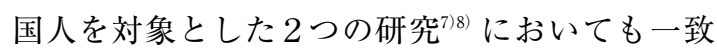
した結果は得られていない。

2. 内リンパ恒常性に関与する分子

antiquitin 1 （遺伝子 $A T Q$ 1）は水バランスを調 節する機能を有し, 胎児蝸牛 cDNA ライブラリ 一上にもクローンされている。しかし, 家族性メ ニエール病を含むメニエール病例を対象とした研 究では ATQ 1 との関連は認められなかった ${ }^{11}$ 。

KCNE K+チャネル (KCNE 1-5) は, 種々の器 官においてイオンや水輸送に重要な働きをもち, 内耳では KCNE 1 と KCNE 3 の mRNAがそれぞ れ血管条と内リンパ囊に発現する。Doi ら ${ }^{12)}$ は, 
Equilibrium Res Vol. 71(4)

表 1 メニエール病と HLA

\begin{tabular}{|c|c|c|c|}
\hline 報告者, 年 & 人種 & 症例数 & HLA アリル \\
\hline Xenellis ら, 1986 & イギリス人 & 41 & $\begin{array}{l}\text { HLA-Cw } 7 \\
\text { HLA-A } 1 \\
\text { HLA-B } 8\end{array}$ \\
\hline Koyama ら, 1993 & 日本人 & 20 & $\begin{array}{l}\text { HLA-DRB 1*1602 } \\
\text { HLA-Cw } 4\end{array}$ \\
\hline Yeo ら, 2002 & 韓国人 & 39 & $\begin{array}{l}\text { HLA-Cw*0303 } \\
\text { HLA-Cw*0602 } \\
\text { HLA-B } 44 （ \text { 負の関連） } \\
\text { HLA-Cw*0102（負の関連） } \\
\text { HLA-DRB 1*15 }\end{array}$ \\
\hline Коo ら, 2003 & 韓国人 & 41 & $\begin{array}{l}\text { HLA-DRB } 1 * 0405 \\
\text { HLA-DRB } 1 * 1201 \\
\text { HLA-DRB } 1 * 13 \text { (負の関連) }\end{array}$ \\
\hline Lopez-Escamez ら, 2007 & スペイン人 & 80 & HLA-DRB $1 * 1101$ \\
\hline
\end{tabular}

孤発の日本人メニエール病例において $K C N E 1$ の多型 $112 \mathrm{G}>\mathrm{A}$ と KCNE 3 の多型 $198 \mathrm{~T}>\mathrm{C}$ が メニエール病発症と関連することを報告した。し かし, Doi らの研究を追試した Campbell ら ${ }^{13)}$ の 報告では, 白人においては KCNE 1 や KCNE 3 多型との関連は認められなかった。

$\mathrm{Na}^{+}, \mathrm{K}^{+}$-ATPase は, 内リンパのイオン恒常性 に重要な働きをすると考えられている。細胞骨格 タンパク adducin は $\alpha, \beta, \gamma$ のつのサブユニッ トにより構成され, それぞれ $A D D$ 1, $A D D 2, A D D$ 3 によりコードされる。460位のグリシンをトリ プトファンに置換（460 Trp）したadducin $\alpha$ 夕 ンパクを導入した細胞では, $\mathrm{Na}^{+}, \mathrm{K}^{+}$ポンプの 活性が高まることが報告されている。メニエール 病28例に対する $A D D$ 1, $A D D 2, A D D 3$ の症例 対象研究では, $A D D 1$ の $460 \operatorname{Trp}$ のアリルを有 する頻度がメニエール病で有意に高いことが示さ れた ${ }^{14)}$ 。

水チャネル aquaporin については, $A Q P$ 1, $A Q P$ 2, $A Q P 3, A Q P 4$ の解析が行われている ${ }^{15)}$ 。 ニエール病34例中11例において $A Q P 3$ にホモ接 合の $105 \mathrm{G}>\mathrm{C}$ が同定されたが，コントロール100 染色体には認められなかった。

3. ストレスに関与する分子

熱ショックタンパク（heat shock protein）は
ストレスタンパクとも呼ばれるが, Kawaguchi ら ${ }^{16)}$ はメニエール病49例を対象に heat shock protein 70 を標的とした症例対象研究を施行した。 heat shock protein 70 は, 前述の $M H C$ (HLA) 遺伝子群に含まれる $H S P A 1 A, H S P A 1 B, H S P A$ $1 L$ によりコードされる。HSPA 1 A の190Cアリ ルはメニエール病で有意に頻度が高く, メニエー ル病の発症に関連するものと考えられた。

PARP-1 がコードする Poly (ADP-ribose)polymerase 1 (PARP-1) は核内酵素であり, ラ セン神経節細胞に存在し, 内リンパ水腫発生後に 生じるストレス環境下でラセン神経節細胞の生死 に関与すると考えられている。PARP-1 のプロ モーター領域に存在するCA マイクロサテライト は, リピート数の多いアリル $(\mathrm{CA})_{17-20}$ の頻度が 両メニエール病例で有意に低く, メニエール病発 症に防御的に働く可能性が示されている ${ }^{17)}$ 。

一酸化窒素合成酵素 (nitric oxide synthase: NOS）は神経型 NOS（遺伝子 NOS 1), 誘導型 $\operatorname{NOS}$ (遺伝子 $\operatorname{NOS} 2 A, 2 B, 2 C$ ), 内皮型 NOS （遺伝子 NOS 3）に分類され，モルモットの内リ ンパ水腫モデルではNOS と酸化ストレスがラセ ン神経細胞の消失に関与することが報告されてい る。しかし, NOS 1 と NOS $2 \mathrm{~A}$ の症例対象研究 ではメニエール病との関連は認められなかっ 
た ${ }^{18)}$ 。

4. 自己免疫, 炎症に関与する分子

T lymphocyte-associated protein 4 をコードす る CTLA 4 と lymphoid tyrosine phosphatase nonreceptor type 22 をコードするPTPN 22 は, 各種 自己免疫疾患との関連が報告されている。両側の メニエール病に対する症例対象研究では, CTLA 4 との関連は認められなかったが, PTPN 22 の $1858 \mathrm{C} / \mathrm{T} ア リ ル$ 頻度はメニエール病で有意に高 いことが報告されている ${ }^{19)}$ 。

$\mathrm{F} C \gamma$ 受容体である CD $16 \mathrm{~A}$ (遺伝子 FCGR 3 A) と CD $32 \mathrm{~A}$ （遺伝子 FCGR $2 A$ ） は免疫複合体の クリアランスを制御する IgG サブタイプと結合 し, FCGR 3 A の $559 \mathrm{~A}>\mathrm{C}$ と FCGR 2 A の $519 \mathrm{~A}$ $>\mathrm{G}$ はウイルス感染, 関節リウマチ, 全身性エリ テマトーデスとの関連が報告されている。しか し，スペインのメニエール病例においては，これ ら $2 つ の$ 多型との関連は認められなかった ${ }^{20)}$ 。

血管壁の透過性を増加させるような炎症反応 が，血液内耳関門の破綻に関与する可能性があ る。突発性難聴とメニエール病を対象としたイン ターロイキン $1 \mathrm{~A}$ をコードするIL 1 A とインタ ーロイキン $1 \mathrm{~B}$ をコードするIL 1 B の解析にお いて，これらの疾患ではIL 1 A の-889 Tのアリ ル頻度が高いことが示されている ${ }^{21)}$

\section{家族性メニエール病に対する連鎖解析}

Klar ら ${ }^{222}$ は, 常染色体優性遺伝形式のスウェ ーデン人メニエール病 3 家系の連鎖解析により第 12番染色体短腕（12 p 12.3）に遺伝子座を同定し た。しかし, $12 \mathrm{p} 12.3$ 内で狭められた $1.7 \mathrm{Mb} の$ 候補領域にある PIK $3 C 2 G$ に 3 家系に共通する 変異は認められなかった。その後, 2 人以上の家 族内発症のあるメニエール病15家系を対象に関連 解析が行われ, PIK 3 C $2 G$ のエキソン 29 近傍に ある $2 つ の$ 多型がスウェーデン人の家族性メニエ 一ル病に強く関連することが示された ${ }^{23)}$ 。一方, フィンランド人の家族性メニエール病 16 家系で は, $12 \mathrm{p} 12.3$ への連鎖は認められなかった ${ }^{24)} 。$

Adweiler-Harbeck ら ${ }^{25)}$ は, ドイッ人家族性メニ エール病17家系を対象に連鎖解析を行い, 第 5 番 染色体のマーカーD 5 S 644 近傍に suggestive な 遺伝子座を同定した。 2 番目に高い LOD 值を示 した第12番染色体の領域は $12 \mathrm{p} 12.3$ とは異なる ものであった。
次世代シークエンサーを駆使することで，メニ エール病の原因候補遺伝子 SLC 45 A 3 が同定さ れつつある ${ }^{4)}$ 。この研究成果は2010年に京都で開 催された Sixth International Symposium on Meniere's Disease and Inner Ear Disorders にお いてもアイオワ大学耳鼻咽喉科の Smith 教授に より報告されている。チリ人の三世代以上にわた る常染色体優性遺伝形式の家族歴を有するメニエ 一ル病家系において，連鎖解析により 2 つの候補 遺伝子座が認められた。その後, 次世代シークエ ンサーにて得られた SLC 45 A 3 の36塩基欠失 は，家系内全てのメニエール病例で同定された。

\section{まとめ}

メニエール病に対する関連解析では, 症例数も 少なく人種によらず再現性のあるような特定の遺 伝子は同定されていない。一方，DFNA 9 の原因 遺伝子 $\mathrm{COCH}$ とメニエール病との関連が否定さ

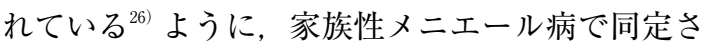
れた原因遺伝子が孤発のメニエール病と無関係で ある可能性がある。しかし，内リンパ水腫がメニ エール病の本態なのか, 続発性に生じた病理組織 学的所見なのかの結論は出ていない。従って, 臨 床症状から診断されるメニエール病例を対象とし た遺伝学的研究が, メニエール病の病態解明と治 療に貢献することが期待される。

\section{文献}

1) 森 望：メニエール病. 小川 郁 編.よ くわかる聴覚障害 一難聴と耳鳴のすべ て一. 156-166頁，永井書店，大阪，2010

2 ) Eppsteiner RW, Smith RJ: Genetic disorders of the vestibular system. Curr Opin Otolaryngol Head Neck Surg 19: 397-402, 2011

3 ) Gazquez I, Lopez-Escamez JA: Genetics of recurrent vertigo and vestibular disorders. Curr Genomics 12: 443-450, 2011

4 ) Oetting WS: Impact of next generation sequencing: The 2009 human genome variation society scientific meeting. Hum Mutat 31: 500-503, 2010

5 ) Xenellis J, Mirrison AW, McClowskey D, et al.: HLA antigens in the pathogenesis of Meniere's disease. J Laryngol Otol 100: 2124, 1986

6 ) Koyama S, Mitsuishi Y, Bibee K, et al.: HLA 
associations with Menière's disease. Acta Otolaryngol 113: 575-578, 1993

7 ) Yeo SE, Park SN, Jeon EJ, et al.: Influence of human leukocyte antigen in the pathogenesis of Ménière's disease in the South Korean population. Acta Otolaryngol 122: 851-856, 2002

8 ) Koo JW, Oh SH, Chang SO, et al.: Association of HLA-DR and type II collagen autoimmunity with Meniere's disease. Tissue Antigens 61: 99-103, 2003

9 ) Lopez-Escamez JA, Vilchez JR, Soto-Varela A, et al.: HLA-DRB $1{ }^{*} 1101$ allele may be associated with bilateral Ménière's disease in southern European population. Otol Neurotol 28: 891-895, 2003

10) López-Escámez JA, López-Nevot A, Cortes R, et al.: Expression of A, B, C and DR antigens in definite Meniere's disease in a Spanish population. Eur Arch Otorhinolaryngol 259: 347-350, 2002

11) Lynch M, Cameron TL, Knight $M$, et al.: Structural and mutational analysis of antiquitin as a candidate gene for Ménière disease. Am J Med Genet 110: 397-399, 2002

12) Doi K, Sato T, Kuramasu T, et al.: Ménière's disease is associated with single nucleotide polymorphisms in the human potassium channel genes, KCNE 1 and KCNE 3. ORL J Otorhinolaryngol Relat Spec 67: 289-293, 2005

13) Campbell CA, Santina CC, Meyer NC, et al.: Polymorphisms in KCNE 1 or KCNE 3 are not associated with Ménière disease in the Caucasian population. Am J Med Genet A 152 A: $67-74,2010$

14) Teggi R, Lanzani C, Zagato L, et al.: Gly 460 Trp alpha-adducin mutation as a possible mechanism leading to endolymphatic hydrops in Ménière's syndrome. Otol Neurotol 29: 824-828, 2008

15) Candreia C, Schmuziger N, Gürtler N: Molecular analysis of aquaporin genes 1 to 4 in patients with Menière's disease. Cell Physiol
Biochem 26: 787-792, 2010

16) Kawaguchi S, Hagiwara A, Suzuki M: Polymorphic analysis of the heat-shock protein 70 gene (HSPA 1 A) in Ménière's disease. Acta Otolaryngol 128: 1173-1177, 2008

17) Lopez-Escamez JA, Moreno A, Bernal M, et al.: Poly (ADP-ribose) polymerase-1 (PARP1) longer alleles spanning the promoter region may confer protection to bilateral Meniere's disease. Acta Otolaryngol 129: 1222-1225, 2009

18) Gazquez I, Lopez-Escamez JA, Moreno A, et al.: Functional variants in NOS 1 and NOS 2 A are not associated with progressive hearing loss in Ménière's disease in a European Caucasian population. DNA Cell Biol 30: 699708, 2011

19) Lopez-Escamez JA, Saenz-Lopez P, Acosta L, et al.: Association of a functional polymorphism of PTPN 22 encoding a lymphoid protein phosphatase in bilateral Meniere's disease. Laryngoscope 120: 103-107, 2009

20) Lopez-Escamez JA, Saenz-Lopez P, Gazquez I, et al.: Polymorphisms of CD $16 \mathrm{~A}$ and $\mathrm{CD}$ $32 \mathrm{Fc} \gamma$ receptors and circulating immune complexes in Ménière's disease: a casecontrol study. BMC Med Genet 12: 2, 2011

21) Furuta T, Teranishi M, Uchida Y, et al.: Association of interleukin-1 gene polymorphisms with sudden sensorineural hearing loss and Ménière's disease. Int J Immunogenet 38: 249-254, 2011

22) Klar J, Frykholm C, Friberg U, et al.: A Meniere's disease gene linked to chromosome $12 \mathrm{p}$ 12.3. Am J Med Genet B Neuropsychiatr Genet 141 B: 463-467, 2006

23) Gabriková D, Frykholm C, Friberg U, et al.: Familiar Meniere's disease restricted to 1.48 $\mathrm{Mb}$ on chromosome $12 \mathrm{p} 12.3$ by allelic and haplotype association. J Hum Genet 55: 834837, 2010

24) Hietikko E, Kotimäki J, Kentala E, et al.: Finnish familial Meniere disease is not linked to chromosome $12 \mathrm{p} 12.3$, and anticipation 
and cosegregation with migraine are not common findings. Genet Med 13: 415-420, 2011

25) Arweiler-Harbeck D, Horsthemke B, Jahnke $\mathrm{K}$, et al.: Genetic aspects of familial Ménière's disease. Otol Neurotol 32: 695-
700,2011

26) Usami S-I, Takahashi K, Yuge I, et al.: Mutations in the $\mathrm{COCH}$ gene are a frequent cause of autosomal dominant progressive cochleavestibular dysfunction, but not of Meniere's disease. Eur J Hum Genet 11: 744-748, 2003 